Room to Grow: Re-Installing the NCMA Permanent Collection

By: Elizabeth A. Perrill with Katherine McKee, Carlee Forbes, and Laurel Kilgore

Elizabeth A. Perrill, "Room to Grow: Re-Installing the NCMA Permanent Collection," primary author, with contributions by Katherine McKee, Carlee Forbes, and Laurel Kilgore, African Arts vol. 50, no. 4. pp. 46-61. https://doi.org/10.1162/AFAR_a_00374

Made available courtesy of MIT Press and James S. Coleman African Studies Center, UCLA: https://www.mitpressjournals.org/aa

***(C) 2017 Regents of the University of California. Reprinted with permission. ***

\begin{abstract}
:
An ephemeral gesture: What better or more poetic way to open a permanent installation of African art? The conceptual complexity of African art cries out for subtle contradictions that engage the public in a dialogue, a reflection upon what has been erased and what remains.

In June 2017, Washington, DC-based, Nigerian-born artist Victor Ekpuk will install a 30 x 18 foot site-specific wall drawing in the North Carolina Museum of Art's new African art gallery. The installation will be documented during its creation and a year later when it is wiped off with a sponge and water. No lasting physical object will remain; rather a series of relationships and connections will begin. Ekpuk's work, positioned at a right angle to the 18 x 25 foot El Anatsui work Lines that Link Humanity, will bring together two generations of contemporary African artists. This commission has also been a catalyst for significant outreach and internal education at the NCMA.
\end{abstract}

Keywords: North Carolina Museum of Art | visual art | art collections | African art | curation

Article:

$* * *$ Note: Full text of article below 


\title{
exhibition preview
}

\section{Room to Grow}

\section{Re-Installing the NCMA Permanent Collection}

\author{
Elizabeth Perrill, with Katherine Mpeshi McKee, Carlee Forbes, and Laurel Kilgore \\ all photos courtesy of the North Carolina Museum of Art, except where otherwise noted
}

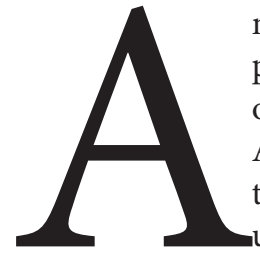

$\mathrm{n}$ ephemeral gesture: What better or more poetic way to open a permanent installation of African art? The conceptual complexity of African art cries out for subtle contradictions that engage the public in a dialogue, a reflection upon what has been erased and what remains.

In June 2017, Washington, DC-based, Nigerian-born artist Victor Ekpuk will install a $30 \times 18$ foot site-specific wall drawing in the North Carolina Museum of Art's new African art gallery. The installation will be documented during its creation and a year later when it is wiped off with a sponge and water. No lasting physical object will remain; rather a series of relationships and connections will begin. Ekpuk's work, positioned at a right angle to the $18 \times 25$ foot El Anatsui work Lines that Link Humanity, will bring together two generations of contemporary African artists. This commission has also been a catalyst for significant outreach and internal education at the NCMA.

Both new and old North Carolinian communities of African heritage will be reflecting on histories of global movement and memory in relation to this artwork and reinstallation. The North Carolina Museum of Art (NCMA) has been providing tours for individuals and families settling in the state through the US Committee for Refugees and Immigrants for several years. This connection is being built upon during the reinstallation. Focus

ELIZABETH PERRILL is the Consulting Curator of African Art at the North Carolina Museum of Art (NCMA) and an Associate Professor at the University of North Carolina at Greensboro. Additionally, she serves as the North American Exhibition Review Editor for African Arts. eperrill@gmail.com

Katherine Mpeshi MCKeE served as Assistant Consulting Curator of African Art at the NCMA 2015-2016.

CARLEE FORBES has been a Curatorial Intern at the NCMA and is currently Curatorial Assistant to Elizabeth Perrill.

LAUREL KILGORE is generously loaning work to the NCMA reinstallation and is an area expert on Malawian art. groups designed to engage community leaders are being organized in conjunction with the Ekpuk installation. Simultaneously, students from several historically black colleges and universities (HBCUs) will be coming in to consider how histories of global migration and slavery bring another perspective to the collections and this poetic installation piece.

These theoretical inquiries and connections emanate into the other curatorial zones of the African reinstallation and are impacting the way the museum conceives of itself as it moves towards the future. Films documenting ephemeral contemporary masquerades will be shown just upstairs from the contemporary film and new media exhibits. Introductory texts will direct visitors out to the NCMA's Egyptian Gallery and Modern and Contemporary Galleries in the East Building. The Ann and Jim Goodnight Museum Park featuring the work of Yinka Shonibare and Ledelle Moe, as well as upcoming temporary exhibits on contemporary African artists, all point to the presence of African art throughout the museum campus.

\section{HISTORY OF THE COLLECTION}

The NCMA collection of art began in earnest in 1968 with the donation of a Shona headrest (Fig. 1), followed quickly in the early 1970 s by the granting of several works to the museum by the Hanes Family and Foundation. The collection has gone through several phases that have increased holdings in either geographic or chronological foci. As one might imagine, acquisitions of the 1970s were largely from Western and Central Africa. The wooden masks and sculptural acquisitions from this period created a strong base from which future curators would build. Additionally, the acquisition of some metal objects opened the door diversifying media represented in the collection (Fig. 2).

My work at the NCMA began in late 2012, when Joyce Youmans, previously of the Nelson-Atkins, and I were asked to fill a gap in the NCMA's curatorial team as Consulting Curators of African art. We were fortunate to inherit the hard work of two accomplished curators in the field of African art, Rebecca Nagy and Kinsey Katchka. From 2006-2011, Katchka ferried the African art collection through the reinstallation process in the new West 


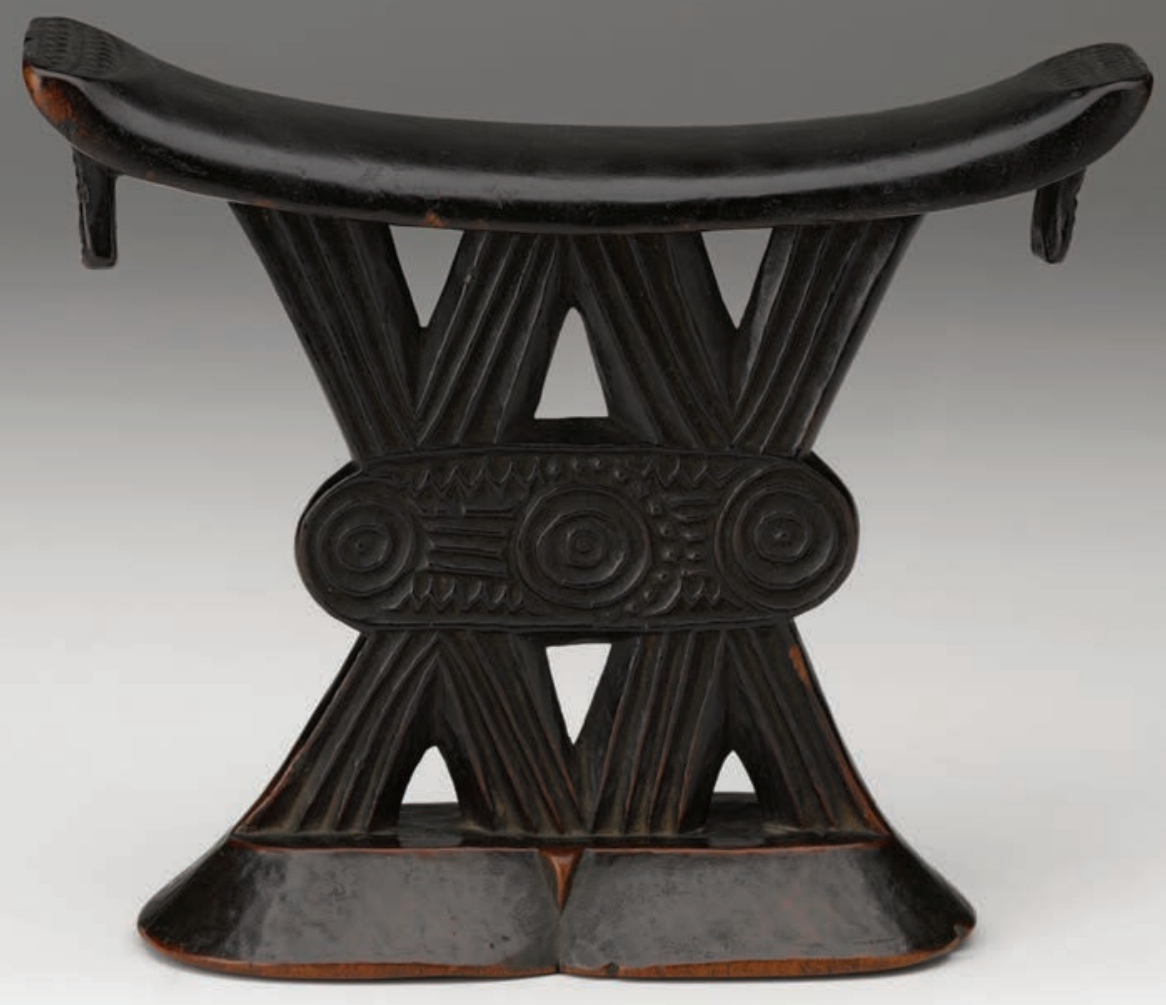

1 Headrest (mutsago)

Central or Southern Shona artist, Zimbabwe, early 2oth century

Wood; $17.1 \mathrm{~cm} \times 20.3 \mathrm{~cm} \times 6.7 \mathrm{~cm}$

Gift of Mr. and Mrs. Cedric Marks, 1968

(G.68.24.6)

Headrests support the neck of a sleeping person and protect an elaborate hairstyle or headdress.

They are also markers of one's allegiances. Terms like Zulu and Shona, associated with cultural traditions and kingdoms, are not static identities. Are there identities or allegiances in your life that are static and some that change?

An individual commissioning a headrest could show the patron's or artist's ties with a group through style. The six-legged headrest in this case features a zig-zag pattern on the side of each leg. This may reference royal jewelry and raised bump designs that became a hallmark of Zulu style.

The Shona headrest features a base and platform separated with an elaborate, flat geometric design composed of V's and circles. There are many variations on Shona style that feature these basic components; the multiple allegiances and stories conveyed by this work are still debated by scholars.

Note: All image captions provided in this preview are advanced drafts of label copy written for a general audience. Didactic questions are emphasized based upon the results of visitor surveys seeking greater personal connections with artworks and collaboration with museum education staff. Initials indicate which coauthor wrote the caption.
Building at the NCMA in 2010. The acquisitions she championed placed the NCMA well ahead of the curve in the collection of contemporary African art, including the monumental El Anatsui that anchors the new gallery (Fig. 3). Katchka's legacy has been maintained with yearly contemporary acquisitions, including works by artists such as Marcia Kure, Elias Sime, Kay Hassan, Zanele Muholi, Viye Diba, and Graeme Williams (Fig. 4).

From 1985 to 2002, Rebecca Nagy built the collection's holdings from the Niger River Delta region, Ghana, Benin, Nigeria, Cameroon, the Democratic Republic of the Congo, and to my delight, South Africa (Fig. 5). Nagy also brought several ceramic works into the collection, a medium that is highlighted in four zones of the reinstallation plan (Fig. 6). A highlight of her time at the museum includes the acquisition of three veranda posts by Lamidi Olonade Fakẹye (Fig. 7) purchased directly from the artist's studio. These posts are complimented by an outstanding loan of a Olówè of Isè door from a local private collection (Fig. 8).

Of course, there are always holes to fill in any collection and a full acquisitions strategy was developed in 2013 to guide the collection into the future. Youmans and I interviewed all museum departments, conducted an inventory, and I have subsequently participated in visitor survey research. Audience research showed that visitors hope to see even more contemporary content. Nevertheless, holes in the historical collection also require attention, as the state museum hopes to show the breadth of African traditions to the public. Objects from South Africa, 


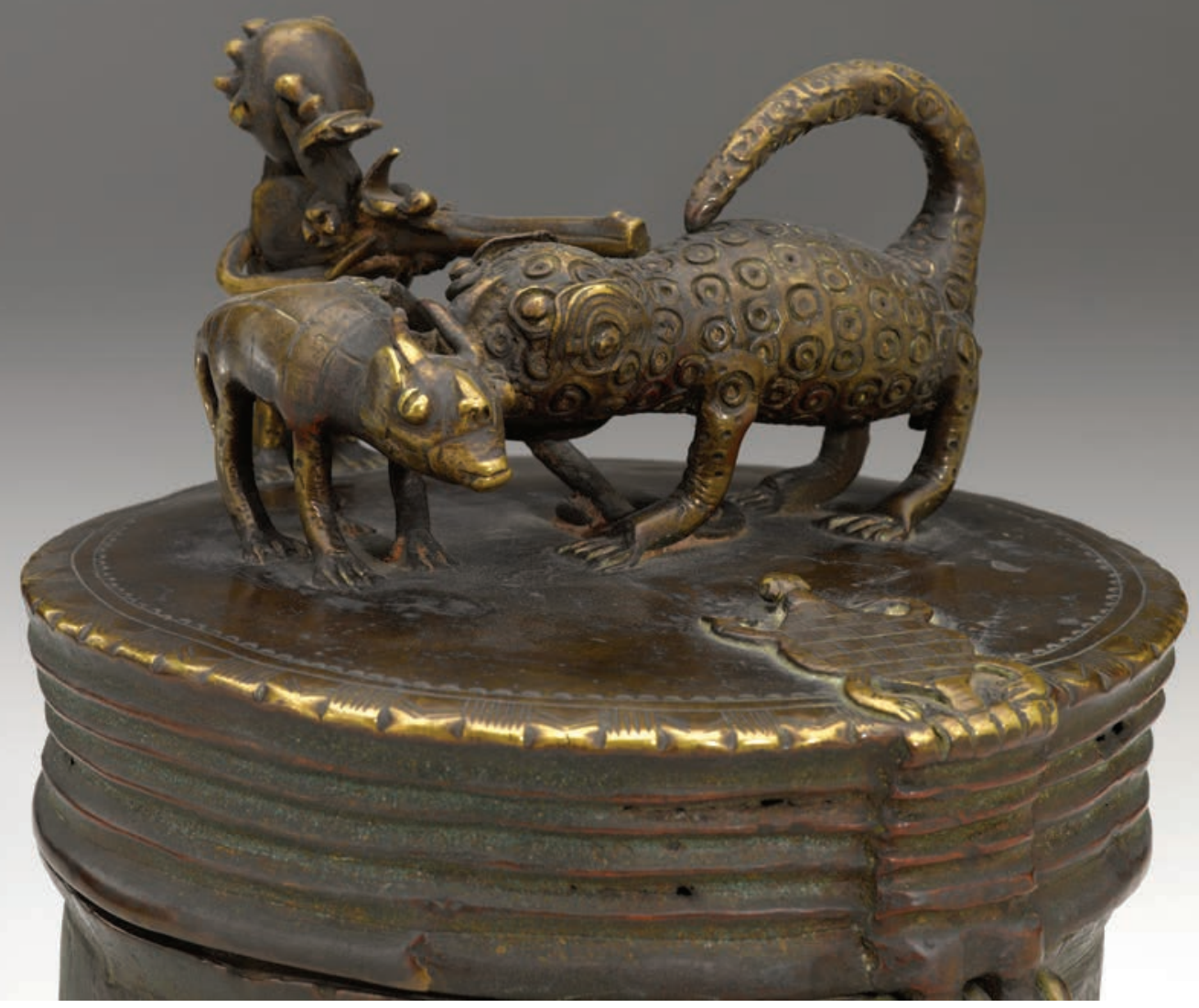

Tanzania, Nigeria, and Mali were added to the collection in the past five years (Fig. 9).

Drawing upon strengths within the states has become a focus of my collections outreach. In 2016, Colleen Kriger introduced me to Nanny Battle Foster, a retired librarian who worked at our institution, UNC Greensboro. Foster was surprised to learn the historical value of the two headrests and snuff container created during the late 1800 s that she had inherited from a family member who had participated in the South African gold rush. Not merely phenomenal examples of Southern African carving, these objects bring to life a legacy of state ties to colonial history. Another significant loan of Chewa masks and ceramics then came from Laurel Birch Kilgore, who moved to North Carolina in 2015 (Figs. 10-12). For me, these donations and loans cemented the fact that the NCMA has an integral role as the state's public art museum, one that draws strength from its people. This mission to build ties across the state through community outreach, local scholarly engagement, and the facilitation of local loans and donations has become a driving force in my own curatorial vision.

To this end, the reinstallation has called upon a broad pool of local art historical talent. Katherine Mpeshi McKee worked from 2015-2106 as Assistant Consulting Curator and UNC Chapel Hill graduate student Carlee Forbes began in 2017 as a paid Curatorial
2 Prestige vessel (kuduo)

Asante artist, Ghana, 19th century Brass; $26 \mathrm{~cm} \times 18.1 \mathrm{~cm}$

Gift of Mr. and Mrs. Gordon Hanes, 1972 (72.19.17)

Asante leaders keep these vessels in shrines, and they are brought out for ceremonial or religious rites. On the lid the artist draws our attention to an event whose outcome remains uncertain: a leopard, stalked by a hunter, has caught an antelope in its jaws. At the hunter's feet, a snake is coiled, ready to strike. This scene can be told from different perspectives. How many proverbs might apply to this cautionary tale of hunter and prey? Do you know any proverbs, and if so, how would you picture them?

Akan metalsmiths adapted the form from similar containers used by Muslim traders for ritual cleansings. Cast in brass and repurposed to store gold dust and precious beads, ornate vessels like this - among the few Asante objects individually owned-belong to royalty, chiefs, and women of high status. Kuduo and their contents were often buried with their owners. 
3 El Anatsui (Ghanaian, b. 1944, active in Nigeria) Lines That Link Humanity (2008)

Discarded aluminum and copper wire; dimensions variable

Gift of Barbara and Sam Wells, 2009 (2009.3)

Utilizing a workshop of student assistants, Anatsui completed this work as a commission for the NCMA within eight to nine months. Anatsui first composed his unique style of metal sculpture using repurposed liquor bottle lids and necks. His material references the bottled liquor that first came to western African as part of colonialism and the trans-Atlantic slave trade. In the NCMA piece, he also incorporates metal remnants left over from newspaper printing processes, evidence of global media and information networks.

The red and yellow palette and textile-like form of Anatsui's undulating surfaces remind many of kente textiles from Ghana, but the artist reminds us not to get stuck on one interpretation. Embracing a concept he describes as nonfixity, Anatsui encourages viewers to think about play, flexibility, aging, and change. Are the Lines That Link Humanity the trans-Atlantic slave trade, international commerce, or international news streams? Are there greater ties that link us through history and our common humanity?
Intern (Fig. 13). Further guidance has been provided by Carol Magee and Victoria Rovine at UNC Chapel Hill, Eli Bentor at Appalachian State, and Lisa Homann at UNC Charlotte. Throughout this five-year reinstallation process, the role of the museum as a state institution dedicated to showing the expansive role of art in Africa and to engaging North Carolinians have been at the forefront of my thinking.

\section{DESIGNED TO DRAW IN}

To display the full scope of the NCMA African collection and to draw in a range of statewide donations and loans, the museum needed to expand upon the 2010 installation. When Youmans and I interviewed Education, Design, Security, and Conservation staff, all attested that the 2,000 square foot rectangular gallery was too crowded. We created a conservationally sound annual reinstallation plan in 2014 that highlighted various geographic foci. However, with a reduced number of works permanently on view, the result was a compromise at best.

After a brief hold on reinstallation, in 2015 the museum received a grant that would both revitalize the modernist East Building and provide an expanded site for the African collection.






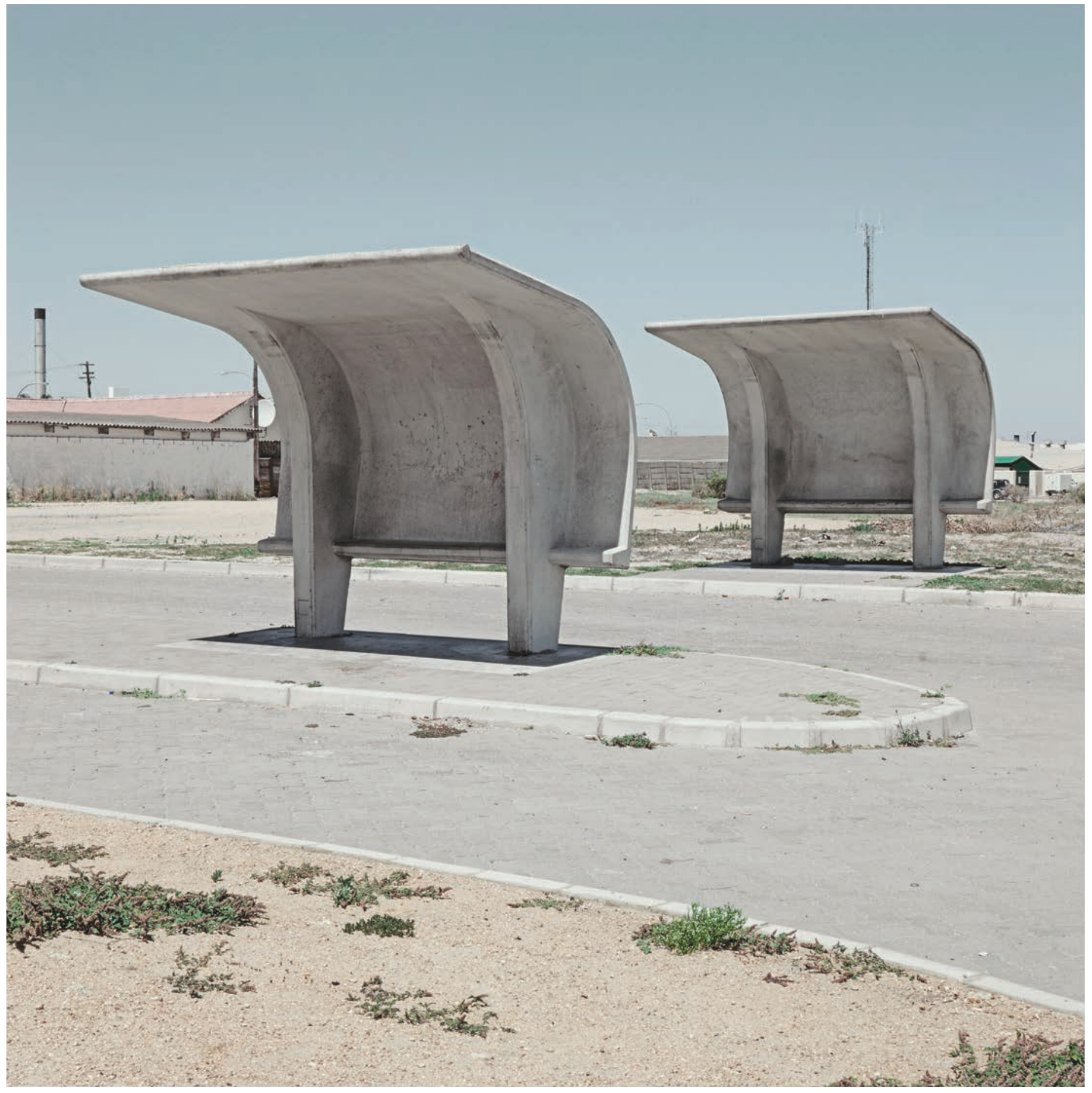

4 Graeme Williams (South African, b. 1961)

New Bus Shelters, Laalplek, South Africa, 2010 (Marking Time Series, 2008-2012) (2010)

Archival digital print on Hahnemühle photo rag; sheet: $91.4 \mathrm{~cm} \times 91.4 \mathrm{~cm}$

Purchased with funds from the African and African American Art Purchase Fund, 2016 (2016.15.1)

Williams's photography captures incomplete, reinterpreted, or abandoned spaces. Often his urban landscapes include modernist buildings found throughout the continent of Africa and the world. Modernist architecture is often associated with poured concrete structures that became a common international style during the 1950s. The coffered, recessed ceiling of the NCMA's West building hearkens back to these same roots.

In South Africa the apartheid system of legally enforced racial segregation was at its height from the 1950 s to the 1980 s, precisely during the rise of modernist architecture. These eerily still bus shelters and the low tough plants growing from the cement landscape may be uncanny allusions to apartheid's migrant labor system. Many black South Africans commute from townships (urban areas originally designated for black South Africans only) to work in mines or cities, this is a lingering hallmark of life that began during apartheid. But, why are there no figures at these new bus shelters? The absence of human figures is a haunting conundrum. 


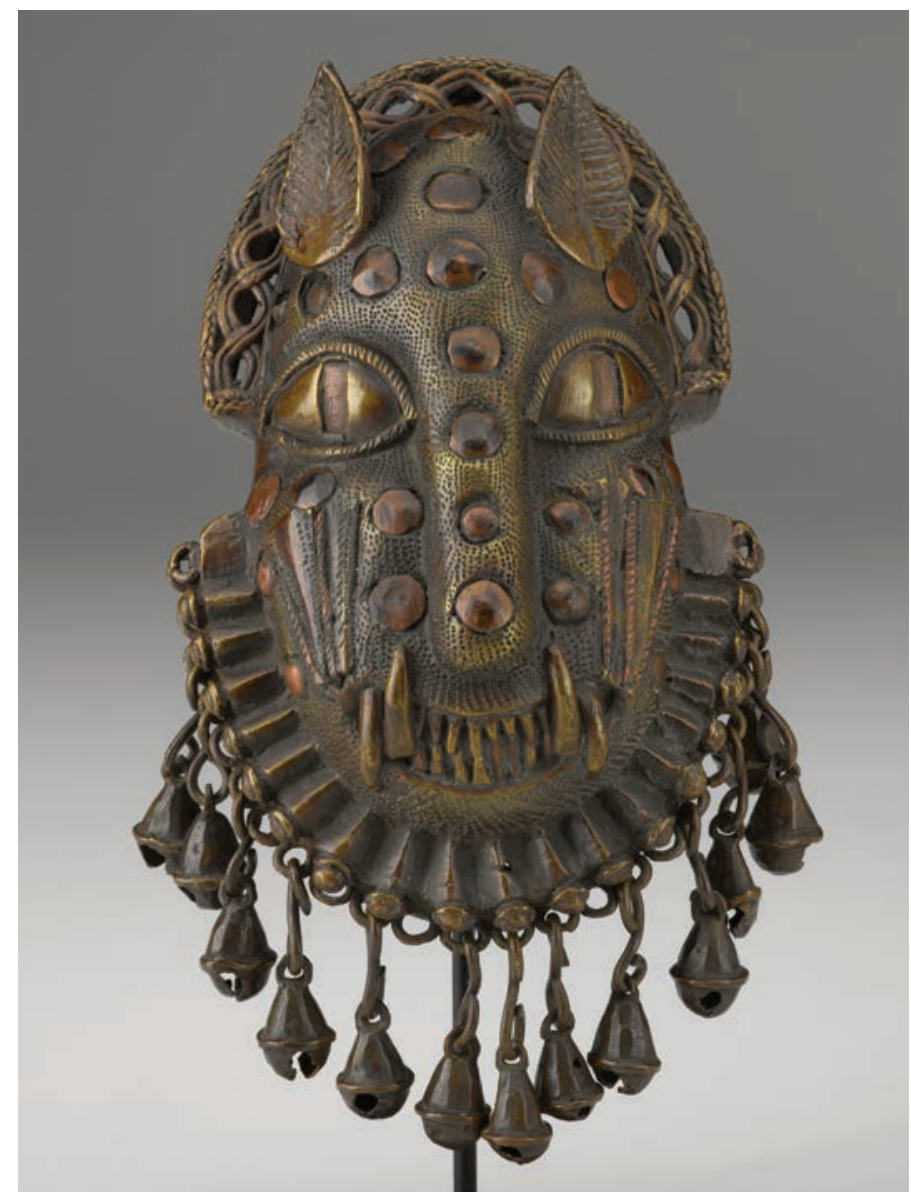

5 Leopard hip pendant

Edo artist, Benin Kingdom, Nigeria, c. 18th century

Cast brass and copper inlay; $22.9 \mathrm{~cm} \times 14 \mathrm{~cm} \times 6.4 \mathrm{~cm}$ Purchased with funds from the bequest of W.R.

Valentiner, by exchange, 99.2

In the Benin Kingdom, the leopard was valued both for its terrifying ferociousness and its cunning intelligence. This powerful symbol could only be associated with the king, or Oba, and the most powerful members of his court. Pendants like this one were worn around the waist and helped to identify an individual's rank within the court. The right to wear a leopard pendant would only be granted to a limited set of courtiers, often warriors.

The hip pendant displayed in this case demonstrates characteristic depictions of leopards by Edo artists including: leaf-shaped ears, overlapping fangs, large eyes, and geometricized whiskers. By placing copper tacks inside the mold before the casting, the artist highlights and differentiates the leopard's spots. The small metal bells attached to the mask's lower edge adds a sonorous component to this visually impressive ceremonial object.

A $\$ 500,000$ grant was secured from the William R. Kenan, Jr. Charitable Trust to reinstall the African collection in the 6,000 square foot entry level space. The new African gallery is three times the previous footprint and consists of two entry corridors, two angled side galleries, and a double story interior atrium with flanking side galleries (Figs. 14-15).

This expanded permanent collection gallery is complemented by a three-room interactive space on the same level. This interpretive space will focus on Central and Western African textiles for three years. Kuba cloth, bogalanfini, and kente traditions will be the initial foci, with each textile tradition receiving a full year

6 Palm wine vessel with figures and bracelets (kuh mendu)

Babessi artist, North West Provence, Cameroon, ca. 1975

Earthenware; $44.5 \mathrm{~cm} \times 40.6 \mathrm{~cm}$

Purchased with funds from the State of North Carolina, by exchange 1999 (99.6.2)

Among the Wushi-speaking people of Babessi, pottery is considered a gift of God to women. As mothers, potters, and farmers, women have roles that are nurturing and generative, essential for the continuation of community life. Linguistically similar terms equate a woman's ability to give birth with the creation of pots.

These three pots serve a variety of functions. The pot with the lizard holds water. The smaller vessel holds stew or vegetables accompanying a porridge. The pot with figures (shown here) holds palm wine. Palm wine is shared on many secular and spiritual occasions. Two human figures, one atop the other, are separated by bands of bracelets punctuated by cowrie shells, all references to royalty and control over people. The openwork rim repeats the undulating rhythm, while the overall dense patterning of the nonfigurative area accentuates the vessel's beautiful shape.

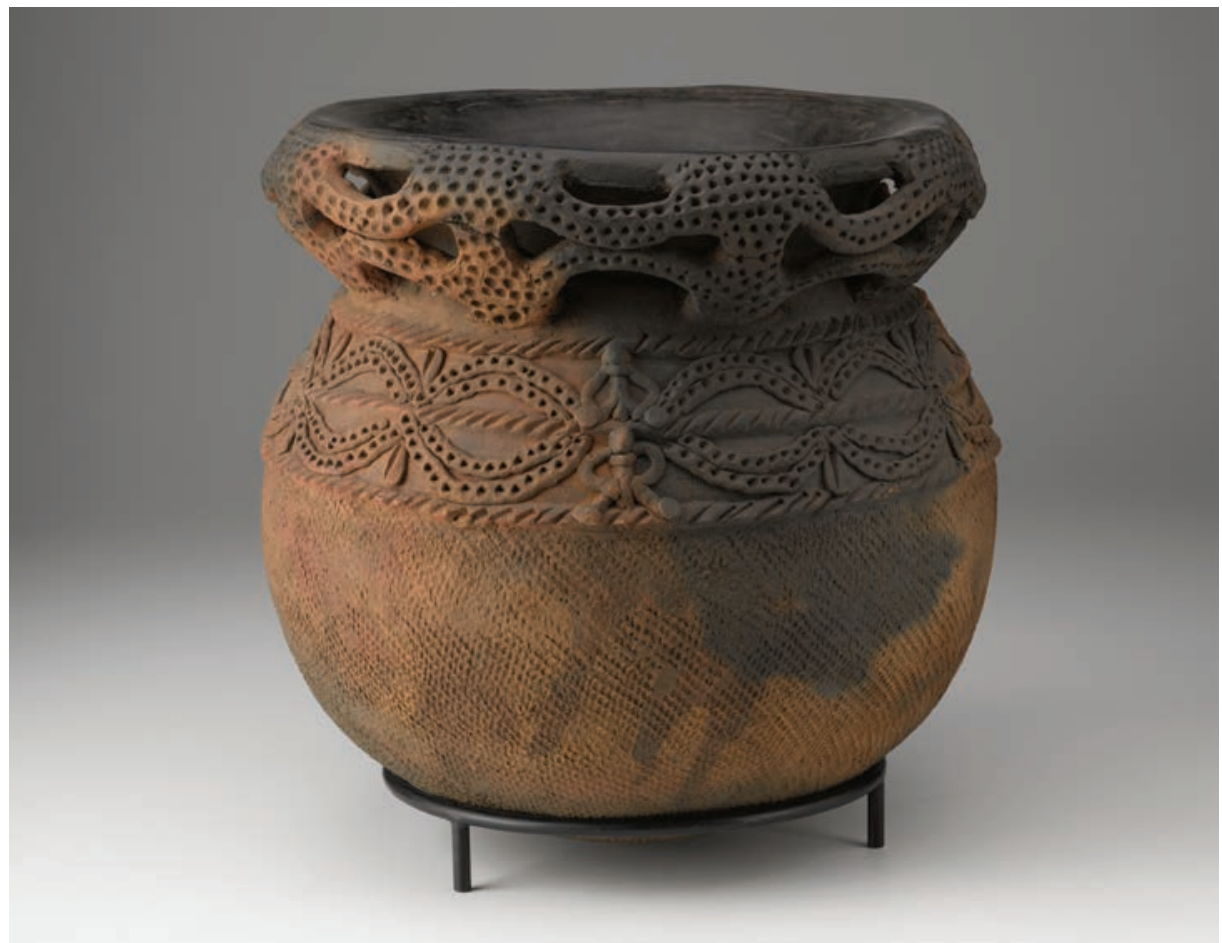



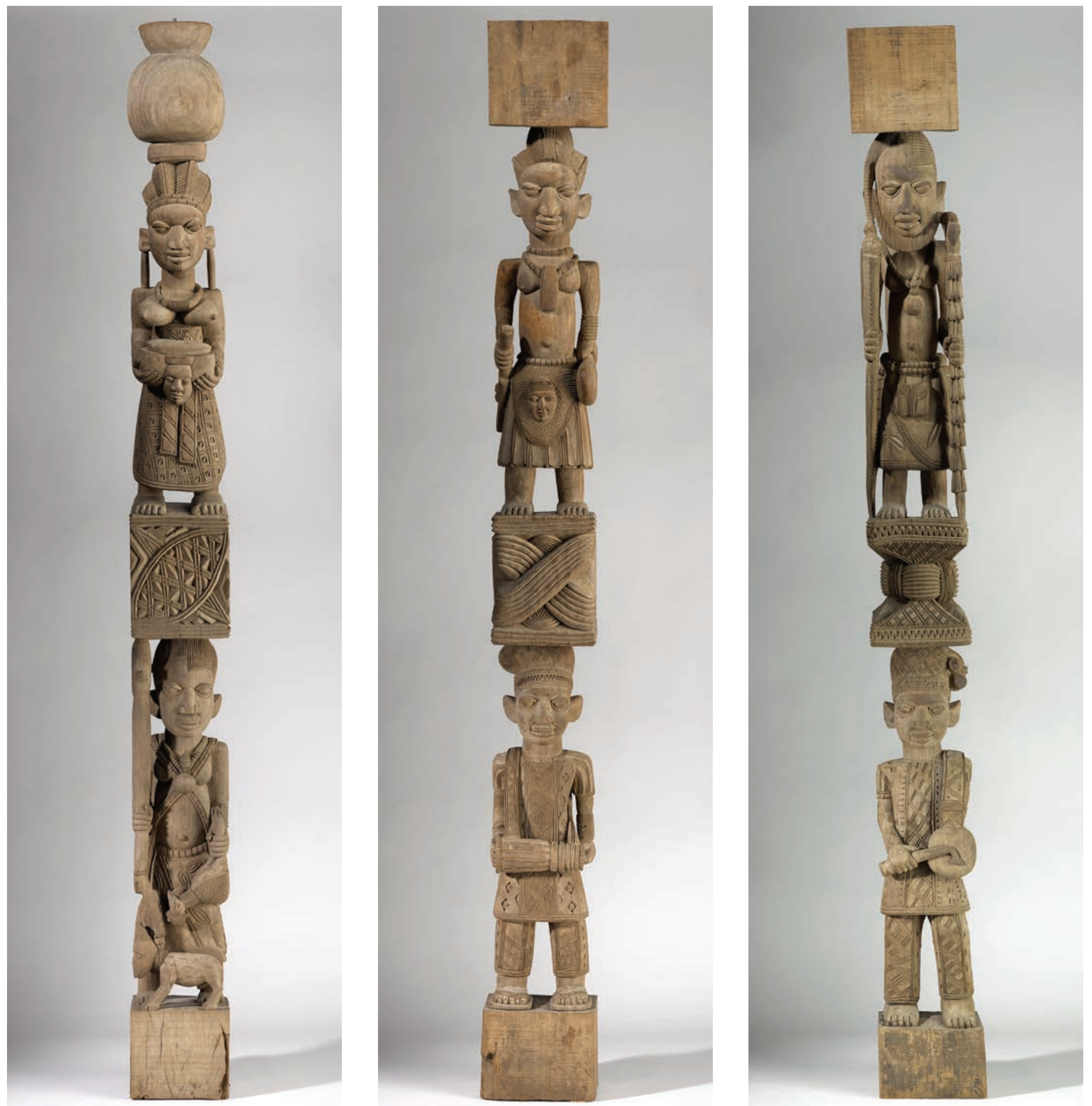

7 Lamidi Olọnade Fakẹye (Nigeria, 1928-2009)

(left) Veranda post with priestess of Oshun and priest of Ogun

(center) Veranda post with priest of Shango and bata drummer

(right) Veranda post with divination priest (babalawo) and drummer (1984)

Iroko wood; left $266.7 \mathrm{~cm} \times 24.1 \mathrm{~cm} \times 24.1 \mathrm{~cm}$; center $265.4 \mathrm{~cm} \times 25.7 \mathrm{~cm} \times 24.4 \mathrm{~cm}$; right $258.4 \mathrm{~cm} \times 24.1 \mathrm{~cm} \times 24.1 \mathrm{~cm}$

Purchased with funds from the North Carolina State Art Society (Robert F. Phifer Bequest), 2001.9.1, 2001.9.2, 2001.9.3

These three posts depict a range of priestesses, priests, and devotees to the many orisas. The first shows a priestess to Oshun, a water orisa, and a priest to Ogun, the warrior orisa of metalwork and hunting. The second illustrates a priest of Shango, the orisa of thunder and lightning, and a drummer playing a small drum. The final post includes a diviner, with many of his divination instruments, and a musician playing a small drum held under his arm. You will notice that Fakeye has carefully placed attributes with each figure that makes him or her readily identifiable. The Oshun priestess carries a bowl, the Ogun priest holds an ax, and the Shango priest carries a dance staff.

The NCMA acquired these objects in 2001 directly from the artist. He had carved them in 1984 as part of an eight-post commission for a cultural center in Ibadan. While the Center was never finished, the artist had already carved three posts, which remained in his possession until 2001 . Unlike most objects in this zone, these objects also include the artist's signature. 
8 Ọlówè of Isè (Yoruba, Nigeria, ca. 1875-ca. 1938) Palace door (ilèkun), early 2oth century

Wood, traces of pigment; $193 \mathrm{~cm} \times 106.7 \mathrm{~cm} \times 5.1 \mathrm{~cm}$ Collection of Rhonda Morgan Wilkerson, PhD, $1.2010 / 1$

The palaces of a Yoruba ruler, or oba, often contain elaborately carved sculptures and reliefs that affirm the oba's power. Divided into four registers, this door includes abstracted faces, geometric patterning, and several figures. In the center of the middle register, you may notice a figure in the center with curved legs. This represents a man with the lower half of a mudfish. Mudfish are powerful beings that can move over land and in water. As such, mudfish are frequently used within Yoruba arts to demonstrate the power of leaders and ancestors, who also cross between realms.

A 1958 photograph shows this door installed on the palace veranda. However, when art historian Roslyn A. Walker visited in 1995, she discovered that it had been replaced and was being reused to bridge a ditch. During a renewal of the palace décor, a copy was reinstalled in the King's palace as the entrance to his private chambers, and this version sold.

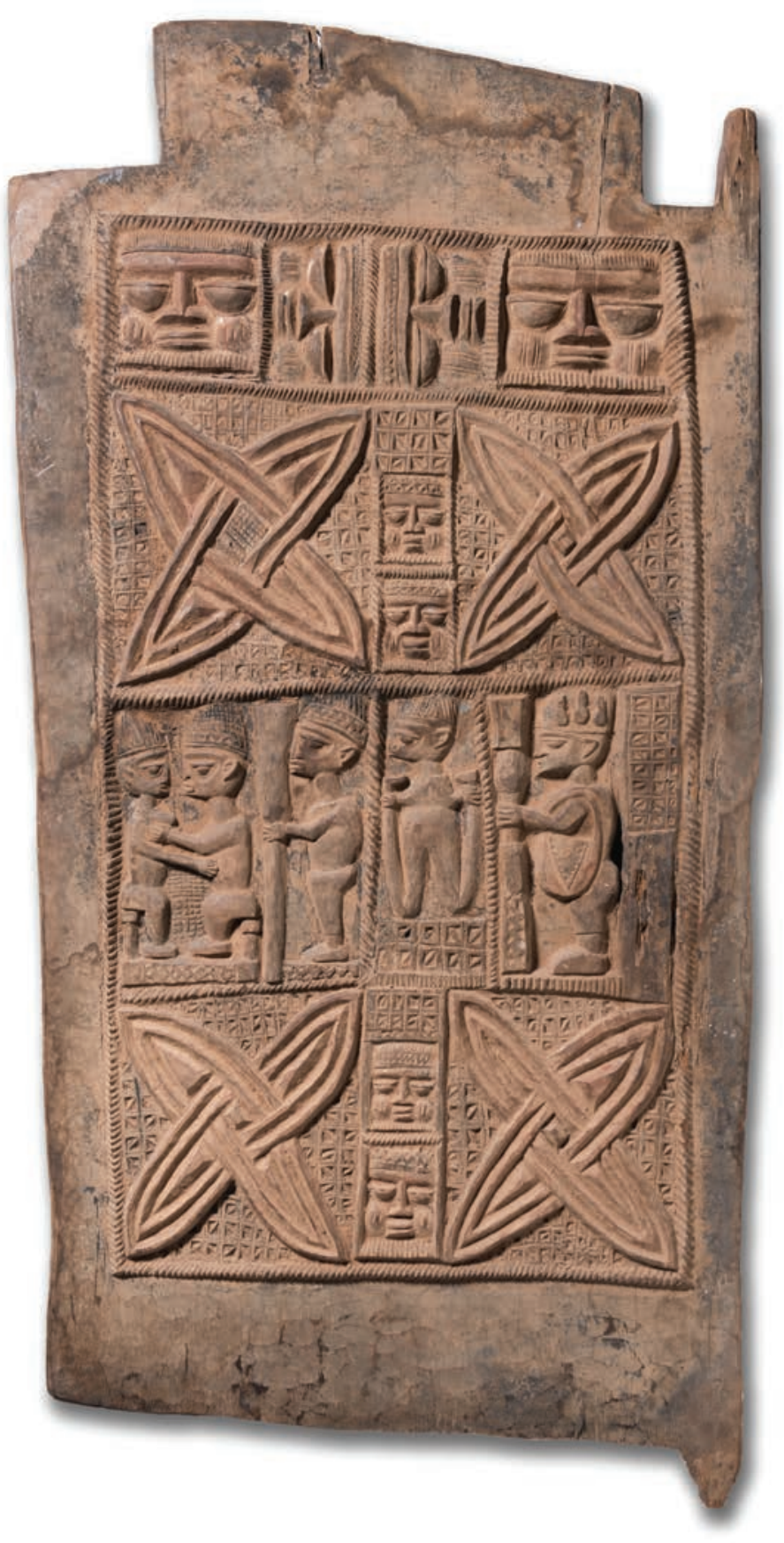

of programming and new interactive activities. During the first year this space will feature a floor-to-ceiling loom, a hands-on pattern activity board, an embroidery area, as well as interactive technology and a reading corner.

The Kenan Grant allows the NCMA to conduct audience research through both online and in-person focus groups, an effort spearheaded by Michelle Harrell, Acting Director of Education. The consulting firm Audience Focus, along with multiple Education, Design, and Curatorial staff, conducted extensive data gathering on audience perceptions and expectations. Through this process, baselines of demographics, viewing preferences, interpretive approach preferences, and levels of understanding were all established in relation to the African art galleries. This process informed educational, curatorial, and design-based interpretive materials.
For instance, each gallery zone bears a two- to three-word title followed by an adjectival cardinal direction description (Northern, Western, Central, Eastern, Southern). Visitor surveys revealed that listing cultural or stylistic attributions in titles discouraged viewers from reading further. The unfamiliar terms stopped readers in their tracks. Moreover, recent research by Susan Gagliardi, the University of Witwatersrand Tribing and Untribing the Archive group, and others complicate the construction of many previously normative categories for art objects, such as ethnic or culture groups. Though these terms do come back into our label writing, they are not the first impression. In the end, contemporary scholarship and audience research pointed in the same direction. Wall panels based on thematic "hooks" and geographic orientations were tested and proved less alienating for visitors: 
- Gold as Regalia: Western Africa

- Art Abounds: Central Africa

- Performance and Scale: Across the Continent

- Geometry and Abstraction: Southern and Eastern Africa

- Divinely Regal: Western Africa

- Modern to Contemporary: Across the Continent and Beyond

- Founding Civilizations: Western Africa

Orientation to these zones is provided through the gallery infographic, located next to an opening text (Fig. 16). The infographic is a map of the gallery with circular areas of pattern, developed from NCMA collection objects. These patterns are then repeated on the major text panels, as seen in the gallery renderings. This visual guidance is designed to provide another point of access and interpretive layer for visitors of every background. Moving forward, summative research is planned, including gathering data on audience perceptions of the installation. Piloting of online apps to create interactive interpretive materials are also on the horizon and are critical layers. GPS-driven beacons and other location-based technologies will ensure the longevity of the permanent installation. By using technologies that are not invasive or permanently obtrusive in the galleries, museums can move with the times and preserve the design coherency of permanent installations.
9 Azolina MaMncube Ngema (South African, b. 1936) Beer pot (ukhamba), ca. 1970-1980

Burnished earthenware, candle wax; H. $25.4 \mathrm{~cm}$, Diam. $27.94 \mathrm{~cm}$

On loan from a private collection

Low-alcohol, sorghum beer was historically a key part of Southern African nutrition and continues to be used as an offering for ancestors and as an expression of hospitality during gatherings. Utilitarian earthenware pots are created for brewing and serving beer. Many families maintain a small altar, or umsamo, a space for presenting beer and meat to ancestors. The earthenware pots are drunk from at funerals, weddings, coming-of-age ceremonies, and other transitional life events. Smaller vessels are passed from person to person. Larger pots can hold beer for a large group and are drunk from with a ladle or cup.

These pots feature a range of geometric patterns created by incised, impressed, and raised-bump techniques. Pots from Zulu-speaking regions are traditionally blackened, a quality that ties them conceptually to ancestors, spirits who prefer dark spaces. Today, pots destined for markets and not used for spiritual presentations are produced in a range of browns or black. 
Returning to the current implementation, two feature walls are listed in the gallery infographic: NC Collections and One Masquerade: Many Faces. These walls were key components of the curatorial vision I developed tied to building in-state relationships. Additionally, these walls home in the interpretive strategy of close looking, which was identified as a key goal for the entire NCMA team.

The NC Collections wall rotates every one to two years and features a collection or collections in the state. The first rotation focuses on ten works from the Bennett College art collection recently donated from the estate of Warren M. Robbins by his widow Lydia Puccinelli Robbins (Fig. 17). I selected this as the opening rotation to highlight the legacy of Bennett College, one of our nation's only women's HBCUs. Museums today need to focus even more explicitly on the community-building roles of the institution. In the current political landscape, it is not merely convenient but critical for public discourse and education to draw in visitors and build networks of mutual support.

One Masquerade: Many Faces consists of six water spirit masks from the Inland Niger Delta Region hung in a vertical orientation.

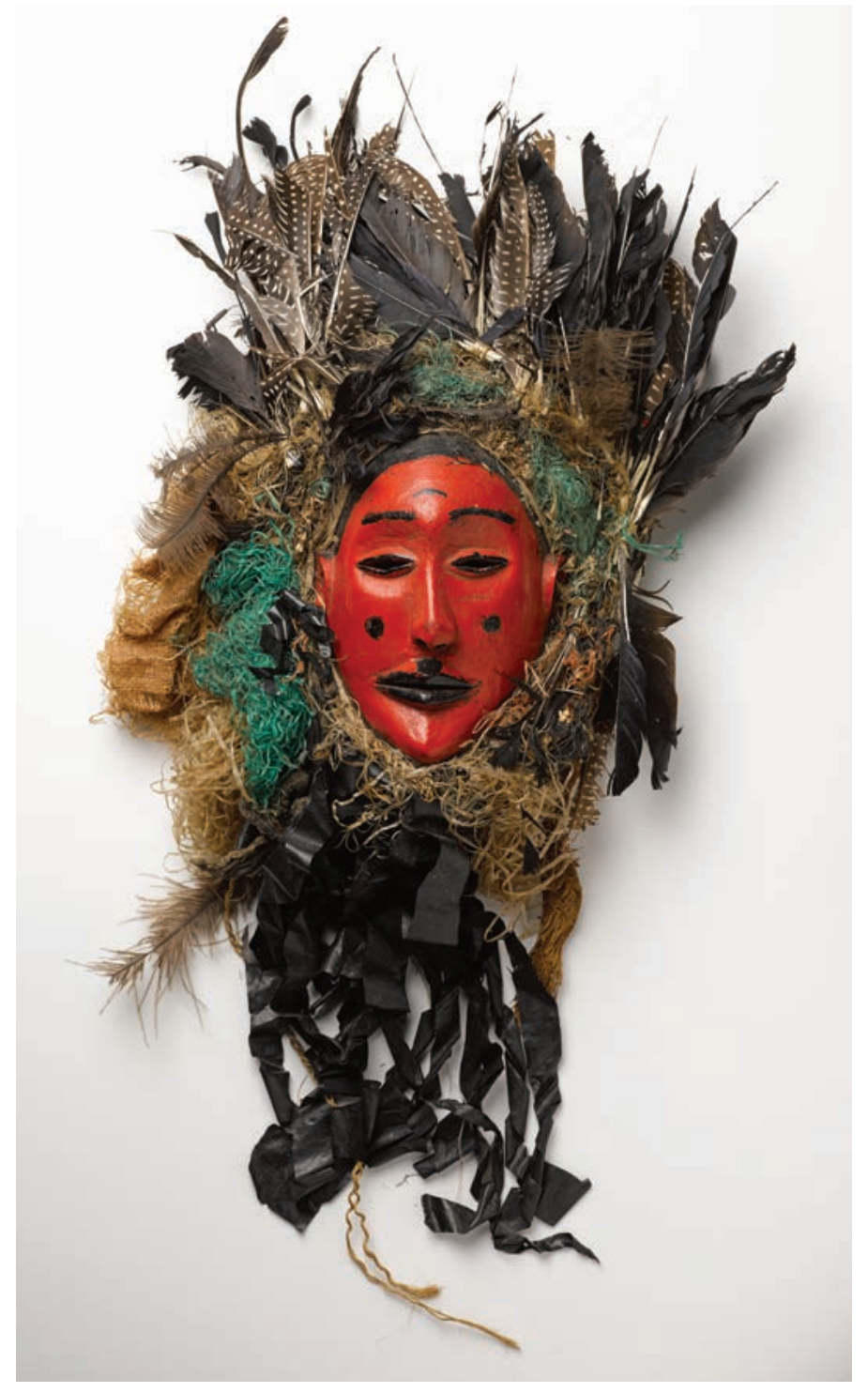

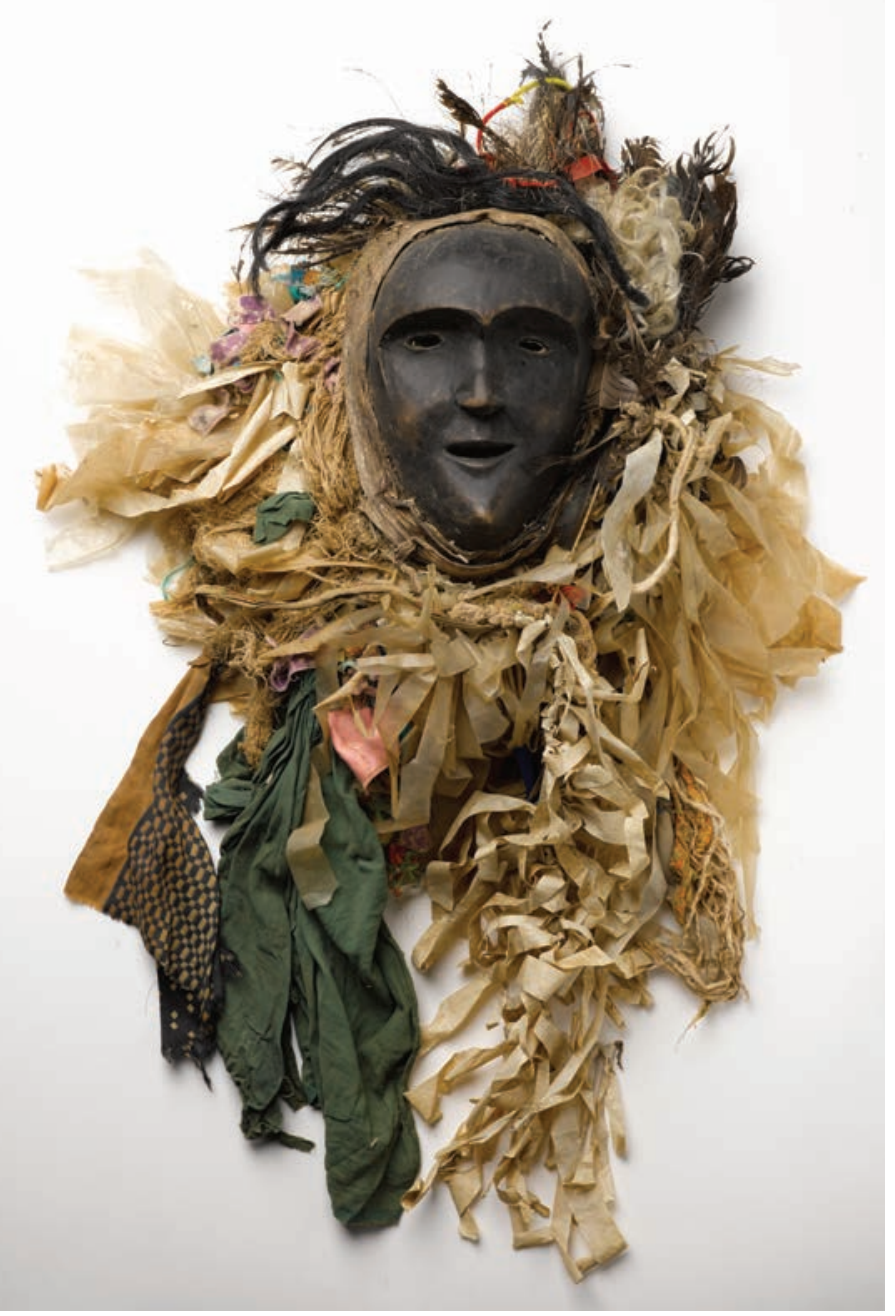

10 (left) Female face mask (namkungwi)

Chewa artist, Malawi, ca. 1950

Wood, feathers, cloth, and paint; Overall h. $109.2 \mathrm{~cm}$, w. $50.8 \mathrm{~cm}$, d. $22.9 \mathrm{~cm}$

Collection of Laurel Birch Kilgore, PhD

11 (above) Male chief face mask (chadzunda)

Chewa artist, Malawi, ca. 1950

Wood, cloth, fiber, and fur; overall h. $81.3 \mathrm{~cm}$, w. 43.2 $\mathrm{cm}$, d. $33 \mathrm{~cm}$

Collection of Laurel Birch Kilgore, PhD

Chewa masks depict portraits of chiefs, namkungwi (respected senior women), foreigners, historic characters, ancestors, and many other entities performed in the Great Dance known as Gule Wamkulu. These masks were often carved as likenesses of senior members of the society. This relative realism sets apart Chewa masks from mask traditions in almost all other African societies. Presented here are mid-twentieth-century masks, one male and one female, performed in rites of passage from youth to maturity, funerals, and the return of the dead in ancestor remembrances.

Rites are organized by the secretive Nyau society, which requires initiation to acquire metaphorical, symbolic, and practical knowledge. Initiations are organized separately for men and women, with different knowledge and roles imparted. Very senior women are trained in both male and female knowledge and are integral in advising the chief and Nyau leaders regarding female initiation and participation. In the moment of performance, Nyau dancers are ritual performers and are not identified as human. 


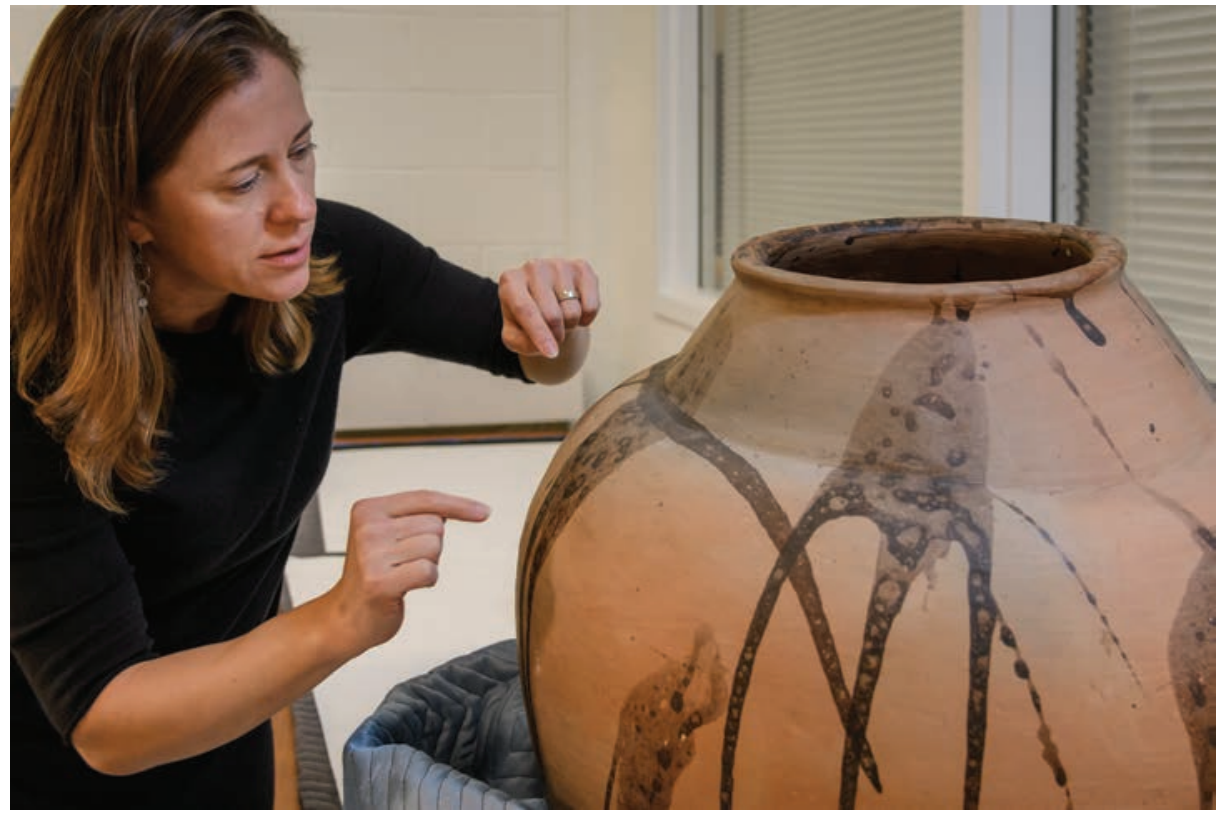

All six are from the collection of Dr. Rhonda Wilkerson. This wall provides an opportunity for comparative looking. The didactic label points out both the variations within this mask genre, as well as histories of display and collecting (Fig. 18). All of the African gallery labels indicate a group, location, or style name, terms that sometimes overlap. On this label the region-Inland Niger Delta Region-is used because the artists' identities may have been varied and possibly somewhat fluid. The convention of listing the term "artist" or "artists" was developed to counter visitor survey data that showed confusion about why utilitarian or performed objects are featured in the museum. The labels subtly assert that in addition to discussions of use and meaning, all creative work in this space is art and all creators artists. The use of the term "artist" is, of course, an act of cultural translation or transfer, but this is a necessary role of museums.
12 Curator Dr. Elizabeth Perrill with a Chewa ceramic vessel, Collection of Laurel Birch Kilgore, PhD.

Photo: Martin W. Kane, UNCG (C) 2017

13 Woman's ceremonial skirt (ncak nsueha) Bushoong artists, Kuba Kingdom, Democratic Republic of the Congo, 2oth century

Raffia, pigment, commercial cloth; $81.28 \mathrm{~cm} \mathrm{x}$ $548.64 \mathrm{~cm}$

Gift of James W. Lankton, 2017 (TR.2016.42/37)

Calling themselves "People of the Cloth" (bambala), peoples of the Kuba kingdom equate their weaving virtuosity with that of their wealth measured in the abundance of status cloth and ceremonial costume. Collectively made and owned by members of a clan, the final function of textiles is to be displayed at funerals and used as burial goods. Ceremonial skirts, such as this one, are also worn for lavish royal ceremonies which culminate in dances and masquerades.

For this 6-yard-long woman's skirt, a senior woman of the ruling Bushoong clan determined the patterns of geometric shapes to be embroidered in closely-worked forward-moving stitches by her clanswomen. Once completed, the approximately 2-foot-square embroideries were returned to the senior woman for assembly.

Here dark threads contrast against three subtle tones of ground, further exaggerated by the juxtaposition of small rectangular pieces that have been hand-stitched back together. When worn, the textile creates undulations that wrap around the woman's body.

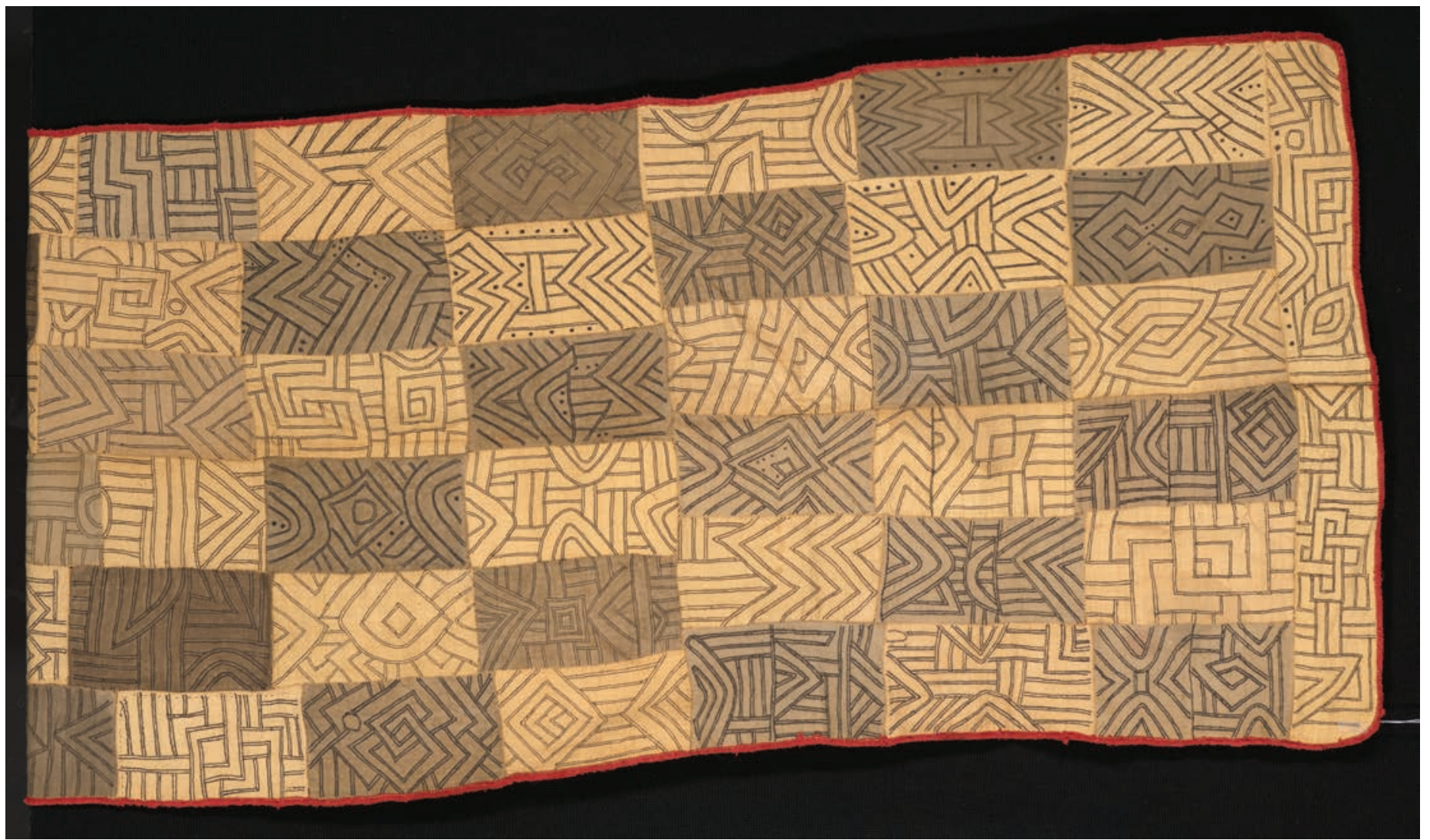




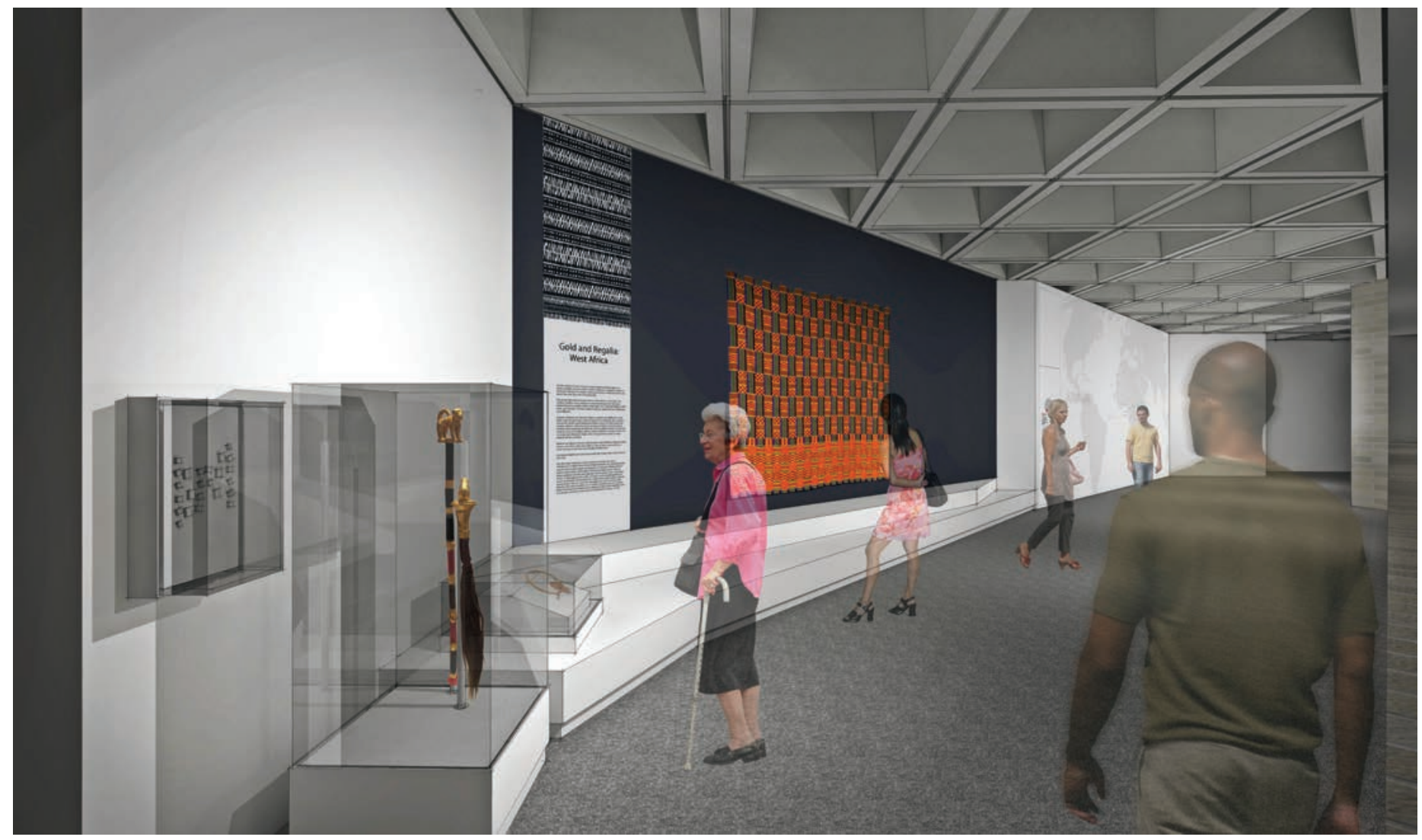

14 (above) Gallery rendering of Niger River Delta Region Sawfish display and Water Spirit film with digitally fabricated screens, Advanced Draft, NCMA Department of Exhibition Design.
15 (below) Gallery rendering of Gold as Regalia: Western Africa zone and Intro Wall Map,

Advanced Draft, NCMA Department of Exhibition Design.

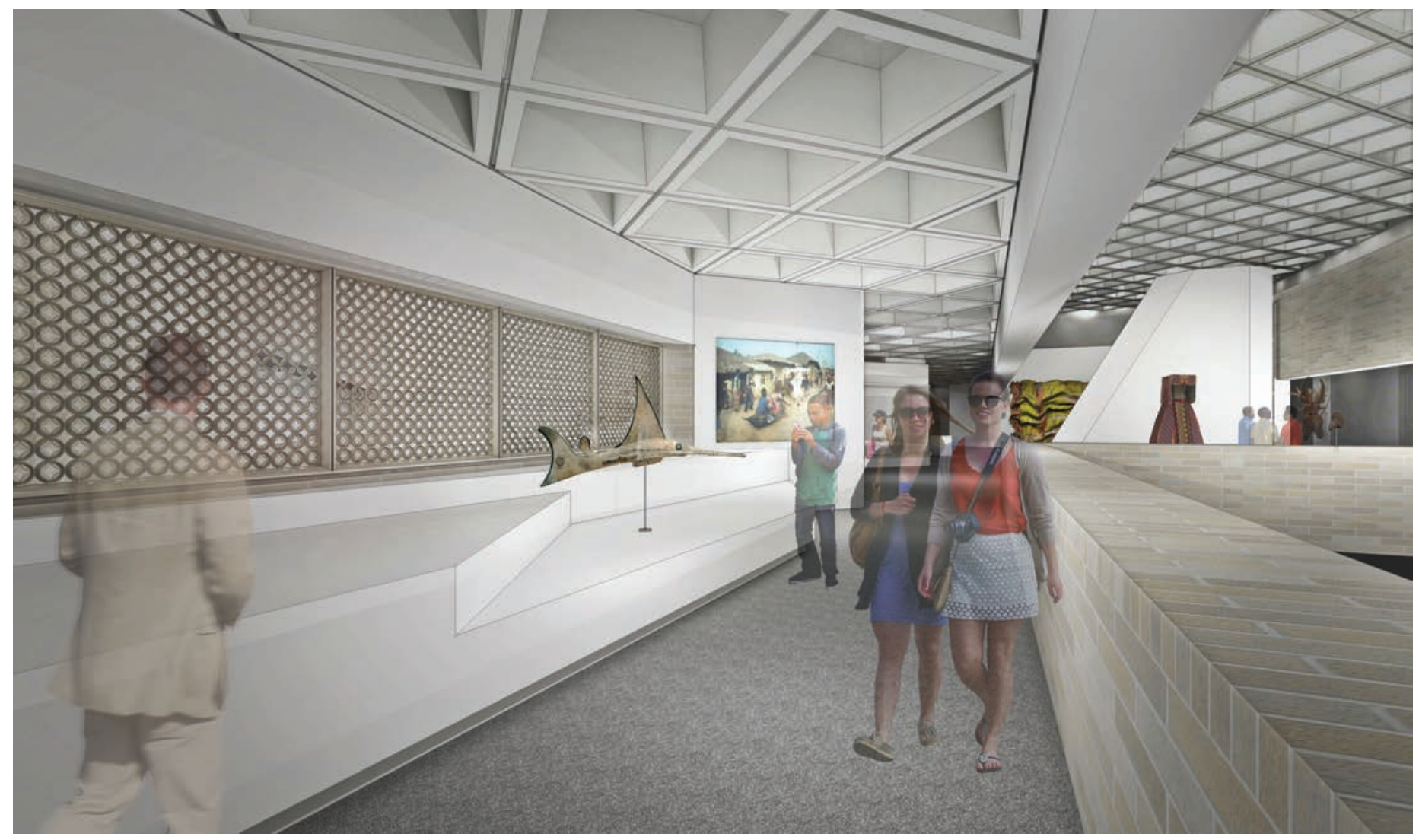


16 Regional African Map and Gallery Map Info-Graphic,

Advanced Draft, NCMA Department of Exhibition Design.



EASTERN

CENTRAL

AFRICA
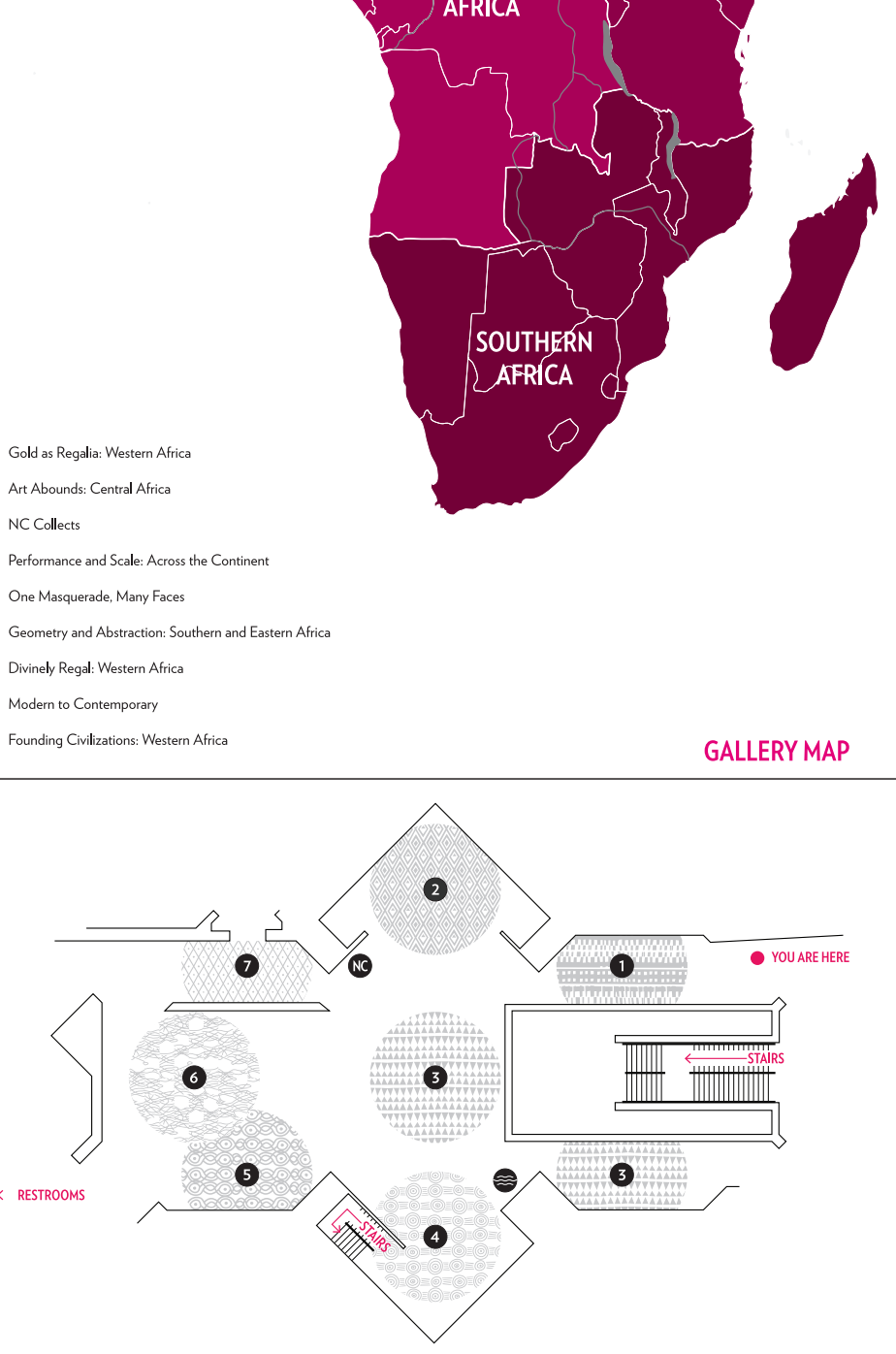

58 african arts WINTER 2017 VOL. 50, NO. 4 


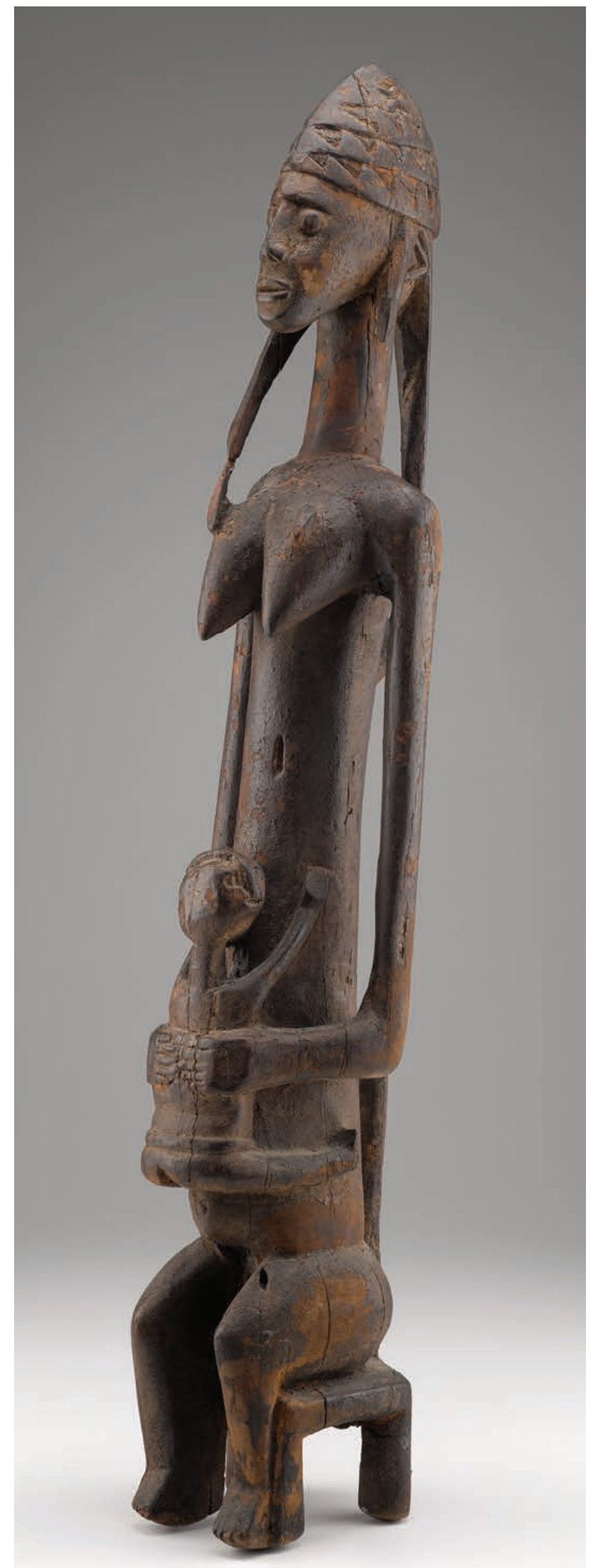

(continued from p. 56)

Around the corner from this grouping are both a sawfish helmet mask (Fig. 19) and a film showing water spirit performances. Thus, viewer will see three contextual orientations of masquerades from the same regional tradition. The film of a 1992 water spirit masquerade, provided by Dr. Martha Anderson, is the oldest of three rotating films. The second film set is drawn from 2009 and 2015 research footage from Dr. Lisa Homann. Various phases of ephemeral koro masquerades held in Tondogosso and Baré, Burkina Faso, are shown in the montage. This selection of an ephemeral masquerade acts as a conceptual reminder that many artworks and components of artworks that are the height of various local aesthetic traditions will never find their way to a US museum. It also provides a poetic link to the ephemeral chalk drawing installation by Victor Ekpuk. The third film is a set of complied 2014 segments provided by Dr. Henry Drewal that show a range of egungun masquerade performances.

There are three full egungun masquerades in the NCMA collections and they are rotated as a key component of a fifteen-foot diameter masquerade platform. Frameworks that held out fabric panels of the egungun, encouraging viewers to see it in the round, had to be removed in the previous installation. There was no space to keep the delicate textiles out of reach. Thankfully, the

17 Figure of mother and child (Jomooni or Gwandusu)

Bamana artist, Jo Society, Mali, early 2oth century Wood; $102.9 \mathrm{~cm} \times 21 \mathrm{~cm} \times 19.1 \mathrm{~cm}$ Loan courtesy of Bennett College

"Things to look at" (mafile fenw) is how practitioners of Jo describe these figures, which are publicly displayed at annual celebrations that convey the spectacle and the power of Jo. Jo and Gwan, a component of it, are associations of initiated men and women living in southern Mali. Gwan is dedicated to helping women conceive and bear children. Society leaders carry the figures in a dancing procession to the community center, where they are washed by women, anointed with shea butter and adorned with beads. This visual renewal expresses the importance of fertility and childbearing, to women and to the entire community.

This mother and child represents the ideal woman and mother. Her extraordinary wisdom and power are evident in her amulet-embellished hat. Decades of annual celebrations have eroded the finely carved marks of scarification that once covered her face, shoulders and torso but not her regal posture. How might this child be viewed by women wishing to have children? 


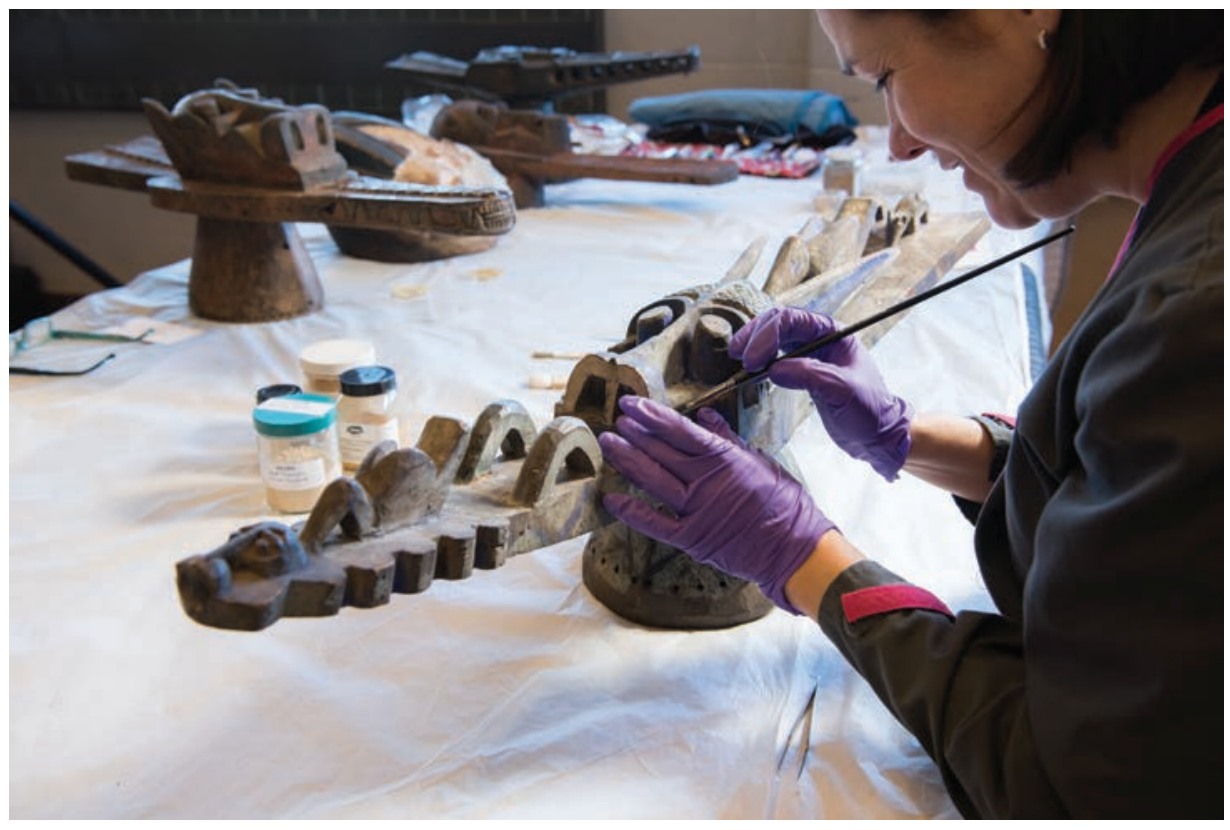

new display will allow for the display of this work with panels flared, as if in motion. While researching various installation techniques, the full African reinstallation team was concerned that wooden masks lacked additional contextualization. Education, Design, and Curatorial staff were impressed by the physicality of Kathleen Bickford Berzock's 2011 raffia reconstructions at the Art Institute of Chicago. Following in the footsteps of this installation, conservation staff are mounting both a Sande Society sowei mask and a chiwara kun mask on full-scale raffia reproductions (Fig. 20). Visitors will see these three masquerade figures from across the building's grand central stairwell.
18 Conservation work underway by Corey Smith Riley, contracted objects conservator, January 2017

Photo: Karen Malinofski, courtesy of the North Carolina Museum of Art

19 Helmet mask, sawfish (oki)

Niger River Delta Region artist, Nigeria, 2oth century

Wood, mirrors, nails, paint, and pigment; 62.2 $\mathrm{cm} \times 47.6 \mathrm{~cm} \times 227 \mathrm{~cm}$

Purchased with funds from various donors, by exchange, 1985 (85.1)

This mask in the shape of a sawfish with its long, sharp nose appears in an annual ljo festival honoring water spirits. Its energetic performance helps to ensure fishing prosperity in the coming year and provides entertainment for the community. A video with excerpts of a sawfish masquerade performance is playing on the screen to your right. Notice the mask's arrival in a canoe, the way the mask balances upon the wearer's head, its energetic movement, its interaction with oth ers performers or the audience, the music accompanying the performance, and its costume.

Take a close look at the mask's materials. Unlike many of the wooden objects in this exhibition that are carved from a single piece of wood, this mask has been skillfully assembled from many components. The teeth and fins are separately attached. The mirrors attached as eyes and on the fins would have flashed in the sunlight during the performance.

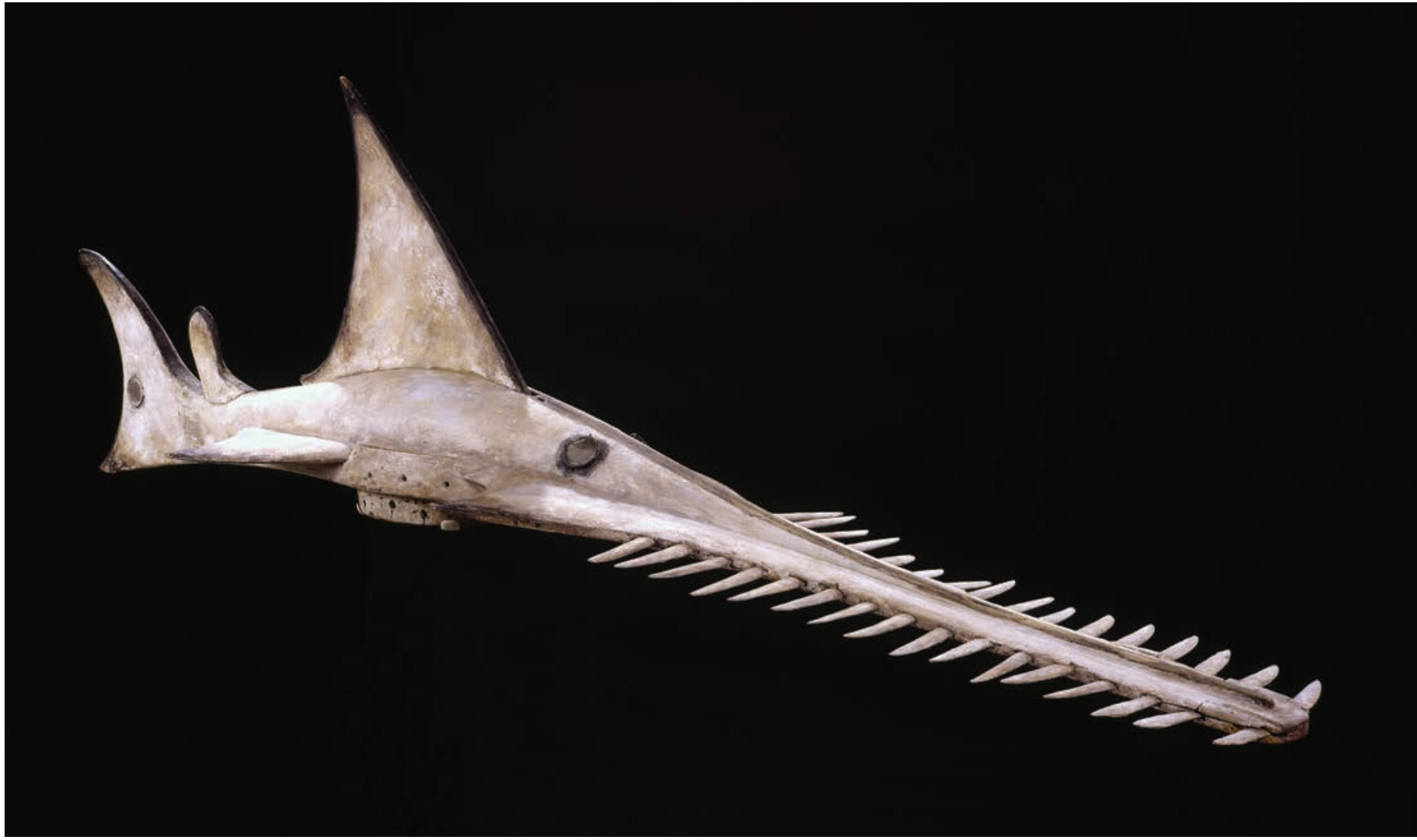




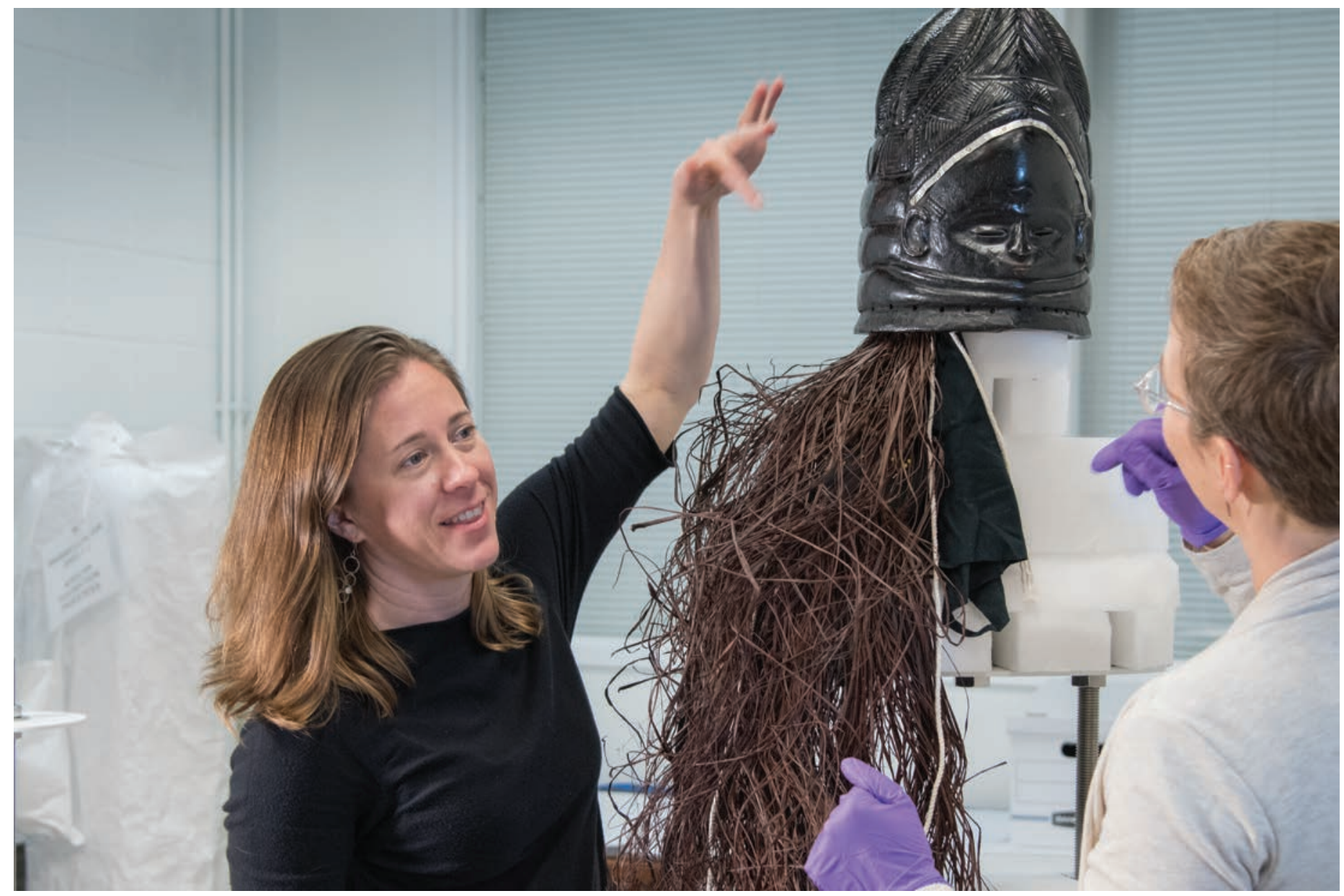

\section{REFLECTING AND MOVING FORWARD}

As I write this preview, the NCMA reinstallation label copy is just one week into the editorial process. Design work is still being refined and conservation staff are hard at work. This is, thus, a reflection on a project that is moving into the future. The galleries will open June 30, 2017, and programming is being planned throughout the summer and early fall, with a major celebration in late September to welcome back the many academic communities that are in close proximity to the NCMA.

The exhibition project has built summative research and evaluation into the overall structure of the reinstallation. Thus, both old and new audiences will be interviewed to see which portions of the exhibition are working and where revisions would be desired during the coming year. Docent education on the African collections and the design of both Africa-focused and museum-wide tours will begin in March. Textiles and photography will rotate according to a sound conservation strategy. New acquisitions and donations will find their places in the new 6,000 square foot space. In other words, the work of the museum will continue.

The room to grow that the new NCMA reinstallation has afforded the African collection cannot be underestimated. Collections policy, education programming, and outreach are continuing to adapt to the physical and mental space that this move has created. Fortunately, the arts of the African continent also continue to fill spaces outside of the African gallery. African artworks are featured in the NCMA's Egyptian Gallery and Modern and Contemporary Galleries in the East Building,
20 Consulting Curator Dr. Elizabeth Perrill and Conservator Stacey Kirby discuss the reconstruction of a Sowei masquerade raffia body covering, January 2017.

Photo: Martin W. Kane, UNCG (C) 2017

as well as in the Ann and Jim Goodnight Museum Park. In 2014, the NCMA celebrated Larry Wheeler's twentieth anniversary as director and the next several years will bring changes; during this time African art will have the space to be front and center as the museum expands and deepens its commitment to serving both North Carolina and the nation.

The curatorial team would like to acknowledge the contributions of the following scholars in assisting with the seemly endless array of details during the process of label writing and updating records: Martha Anderson, Rayda Becker, Lisa Brittan, Elisabeth Cameron, Paul Davis, Patricia Darish, William Dewey, Henry Drewal, Kate Ezra, Lisa Homann, Silvia Forni, Robin Poynter, Janet Stanley, and Gary Van Wyk. We appreciate these and anyone who has been inadvertently left off this list or consulted with following our publication deadline. 